\title{
Analogy and Critical Thinking Skills: Implementation Learning Strategy in Biodiversity and Environment Topic
}

\author{
Ade Suryanda*, Eka Putri Azrai, Mutia Nuramadhan, Ilmi Zajuli Ichsan \\ Department of Biology Education, Faculty of Mathematics and Natural Science, Universitas Negeri Jakarta, Indonesia
}

Received October 8, 2019; Revised January 27, 2020; Accepted March 24, 2020

Copyright $\bigcirc 2020$ by authors, all rights reserved. Authors agree that this article remains permanently open access under the terms of the Creative Commons Attribution License 4.0 International License.

\begin{abstract}
Critical thinking skills can be developed using a learning strategy. Analogy strategy is one of the strategies designed for the passive students with low critical thinking skills. This study aimed to use analogy in biology learning especially in biodiversity and environment topics towards students' critical thinking learning. The study used an experimental pretest-posttest design and a control group design. The research was conducted in 2014. The sample was taken with simple random sampling with 120 students. The results showed that the average value of the pre-post test score of the experimental class was 51.8 and 64.76 , while the average score of a pre-post test of the control class was 47.9 and 58.28. Based on the t-test results obtaining t-value of 2.67, the t-value was higher than t-table, which showed using an analogy in biology learning had an effect on students' critical thinking skills. This is related to the analogy learning process step that students can discuss in the learning process. The conclusion of this study was that analogy strategy had an effect for students' critical thinking skills.
\end{abstract}

Keywords Analogy, Biology Learning, Critical Thinking Skills

\section{Introduction}

The conventional biology learning process usually emphasizes the process of memorizing knowledge, so that it cannot develop students' skills, especially critical thinking skills. The use of learning methods that are low variations and focus on textbooks which make students bored because they only emphasize the low cognitive aspects. The teacher only focuses on improving students 'cognitive abilities at a low level, so that students' critical thinking skills are still relatively not too high [1,2].

Critical thinking is a process that aims to make decisions about a problem and solve it $[3,4]$. Critical thinking skills in secondary schools have not received more attention to be developed optimally. Students' critical thinking skills are needed, such as thinking that involves testing, connecting and evaluating all aspects of a situation or problem, including gathering, organizing, remembering and analyzing information [5,6]. Critical thinking is needed by students in developing their knowledge because in social life, they had problems in daily lives. The existing problems need a good solution so that they can make the right decision. This decision is adjusted with facts and clear information. Students' critical thinking skills can be improved and developed in learning activities. Learning activities lead students to be ready to be confronted with problematic situations and sensitive to problems. One of them can be tried to implement learning activities using an analogy learning strategy. Students'critical thinking is still low and must be improved [7-8]

The analogy is one of the learning strategies that can be applied in delivering topics in class. The analogy can be used to solve learning communication difficulties between teachers and students, especially when students had learning difficulties in understanding new teaching topics that have a similarity in the flow of thinking with previous teaching topics [9]. This similarity in the flow of thought describes the topic being studied so that a referral concept that has been taught and understood well by students is needed. Then, the reference concept is developed to explain the target concept, which is the concept of a new teaching topic. Analogy presents early examples or simple representations of scientific concepts. The teacher usually introduces the introduction first in the explanation to students through word expressions in the form of, exactly, and similarly $[10,11]$.

Introducing the concept of targets to students is the first 
step in learning using an analogy. The second step is to remind analog concepts that are known to students, for example, the analog concept used is lego. After determining the target concept and its analogous concept, the next step is to identify the relevant things of the two, for example, a cell is likened to a lego part so that a lego that is put together can form a toy house while a cell if put together will form a large thing like human. From this, it can be related to the same thing from the analog concept and the target concept and then it can be chosen which analogy is not appropriate between the analog concept and the target concept. In the final stage, students can give conclusions from the topics learned and can make their own cell analogy [12,13]. A comprehensive comparison between the two concepts can broaden the horizons of both teachers and students and prevent misconceptions by maintaining true preconceptions or changing students' concept maps of thinking from false preconceptions to true concepts according to the theory applicable to a particular teaching topic [14-16].

Previous research on critical thinking has been carried out relating to the effects of using various learning models $[15,17,18]$. In addition, research has also been carried out relating to the use of analogy learning strategy $[8,9,19]$. However, there is still little research that measures students' critical thinking using analogy learning strategy. Based on this, it is necessary to conduct research on the use of analogy strategy in biology learning and their effects on students' critical thinking skills. This study aimed to determine the use of analogy in biology learning and their effect on critical thinking skills of high school students on the topic of biodiversity and environment.

\section{Methods}

The study was conducted at SMA Negeri 1 Tambun Selatan in September-October 2014. The research method used was experiment with a quasi-experimental design. The variable investigated in this study is the use of analogy (X) strategy in biology learning on the topic of biodiversity and the environment on students' critical thinking skills (Y). The research design used was a pretest-posttest experimental and control group. The research sample were 120 students consisting of 60 students in the experimental class and 60 students in the control class. Sample was carried out by simple random sampling. Instruments will be given at the beginning of learning (pretest) and the end of learning (posttest). The test was in the form of a description of the topic of biodiversity and the environment to measure students' critical thinking skills.

The indicator instrument of students' critical thinking skills is shown in Table 1. The results of the students' critical thinking skills test scores are classified based on the category of students' critical thinking skills. The critical level thinking category with a score scale consists of five categories, from very high (90-100), high (79-89), moderate (65-78), low (56-64) and very low (0-55) category [20]. In addition to measuring the students' critical thinking skills, observations are also made using the observation sheet of the implementation of learning.

Table 1. Indicator of Students' Critical Thinking Skills question

\begin{tabular}{|c|c|c|}
\hline No. & Aspect & Indicator \\
\hline 1 & Communication & Explain and identify the main problem \\
\hline 2 & Analysis & $\begin{array}{c}\text { Identify the influence of other aspects of } \\
\text { the problem }\end{array}$ \\
\hline 3 & Point of View & $\begin{array}{c}\text { Use your own point of view in solving } \\
\text { problems }\end{array}$ \\
\hline 4 & Information & $\begin{array}{c}\text { Use clear and trusted information } \\
\text { sources }\end{array}$ \\
\hline 5 & Assumptions & $\begin{array}{c}\text { Evaluate assumptions from existing } \\
\text { information }\end{array}$ \\
\hline 6 & Conclusions & $\begin{array}{c}\text { Provide conclusions related to answers } \\
\text { to problems }\end{array}$ \\
\hline
\end{tabular}

Source: Indicators adapted from Ennis [3]

Meanwhile, learning by analogy has implementation steps developed by Glynn, Taashobshirazi, dan Fowler [21], starting from introducing the concept of the target to students. Furthermore, it reminds analog concepts that are known to students, identifies relevant things from analog concepts and target concepts, connects the same things from analog concepts and target concepts, shows where analogy are incompatible between analog concepts and target concepts. The final stage of learning using an analogy strategy is making conclusions.

\section{Result and Discussion}

The highest pretest and posttest scores were 65 and 82 . The results of the pretest and posttest scores in the experimental class are grouped based on 5 categories that have a certain range of values, which can be seen in Table 2.

Table 2. Critical thinking skills score in the experimental class

\begin{tabular}{|c|c|c|c|c|c|c|}
\hline \multirow{2}{*}{ No } & \multirow{2}{*}{$\begin{array}{c}\text { Interval } \\
\text { score }\end{array}$} & Category & \multicolumn{2}{|c|}{$\begin{array}{c}\text { Frequency of } \\
\text { students }\end{array}$} & \multicolumn{2}{|c|}{ Percentage } \\
\cline { 4 - 7 } & & & Pre & Post & Pre & Post \\
\hline 1 & $0-55$ & Very low & 45 & 9 & $75 \%$ & $15 \%$ \\
\hline 2 & $56-64$ & Low & 15 & 21 & $25 \%$ & $35 \%$ \\
\hline 3 & $65-78$ & Moderate & - & 24 & $0 \%$ & $40 \%$ \\
\hline 4 & $79-89$ & High & - & 6 & $0 \%$ & $10 \%$ \\
\hline 5 & $90-100$ & Very High & - & - & $0 \%$ & $0 \%$ \\
\hline
\end{tabular}


The results of the pretest and posttest scores in the control class were grouped by 5 categories that have a certain range of values, which can be seen in Table 3 .

Table 3. Critical thinking skills score in the control class

\begin{tabular}{|c|c|c|c|c|c|c|}
\hline \multirow{2}{*}{ No } & \multirow{2}{*}{$\begin{array}{c}\text { Interval } \\
\text { score }\end{array}$} & Category & \multicolumn{2}{|c|}{$\begin{array}{c}\text { Frequency of } \\
\text { students }\end{array}$} & \multicolumn{2}{|c|}{ Percentage } \\
\cline { 4 - 7 } & & Pre & Post & Pre & Post \\
\hline 1 & $0-55$ & Very low & 52 & 24 & $\begin{array}{c}86,7 \\
\%\end{array}$ & $40 \%$ \\
\hline 2 & $56-64$ & Low & 8 & 20 & $\begin{array}{c}13,3 \\
\%\end{array}$ & $33,3 \%$ \\
\hline 3 & $65-78$ & Moderate & - & 16 & $0 \%$ & $26,7 \%$ \\
\hline 4 & $79-89$ & High & - & - & $0 \%$ & $0 \%$ \\
\hline 5 & $90-100$ & Very High & - & - & $0 \%$ & $0 \%$ \\
\hline
\end{tabular}

The average score of the test before and after treatment in the experimental class and the control class is different. The average pretest score in the experimental class was 51.28 while in the control class was 47.9. The average posttest scores in both classes were 64.76 and 58.28, respectively. Comparison of the average pretest and posttest scores in the experimental class and the control class can be seen in Table 4.

Table 4. Comparison Critical thinking skills score

\begin{tabular}{|c|c|c|c|}
\hline No & Classes & Pre & Post \\
\hline 1 & Experiment & 51.28 & 64.76 \\
\hline 2 & Control & 47.90 & 58.28 \\
\hline
\end{tabular}

The results of the critical thinking skills test scores of the experimental class showed that there were no students in the very high category, high category with 6 students, the moderate category with 24 students, the low category with 21 students, and very low categories with 9 students (see Table 5).

Table 5. Frequency of Students Critical thinking score

\begin{tabular}{|c|c|c|c|}
\hline \multirow{2}{*}{ No } & \multirow{2}{*}{ Category } & \multicolumn{2}{|c|}{ Frequency of students } \\
\cline { 3 - 4 } & & Experiment & Control \\
\hline 1 & Very low & 9 & 24 \\
\hline 2 & Low & 21 & 20 \\
\hline 3 & Moderate & 24 & 16 \\
\hline 4 & High & 6 & - \\
\hline 5 & Very High & - & - \\
\hline
\end{tabular}

The activities carried out by the teacher and students during the study were observed using the observation sheet of the implementation of the learning. The percentage of observations of the feasibility of the experimental class and the control class was shown in Table 6 . The average percentage of the feasibility of the learning done by the teacher in the experimental class is $86.3 \%$. Whereas the average percentage of the learning done by the teacher in the control class is $80.7 \%$. The average percentage of the feasibility of learning carried out by students in the experimental class is known to be $77.2 \%$, while the average percentage of the feasibility of learning carried out by students in the control class is known to be $80.7 \%$, for details in Table 6.

Table 6. Feasibility of learning percentage

\begin{tabular}{|c|c|c|c|}
\hline No & Classes & Teacher & Students \\
\hline 1 & Experiment & $86.30 \%$ & $77.20 \%$ \\
\hline 2 & Control & $80.70 \%$ & $80.70 \%$ \\
\hline
\end{tabular}

Hypothesis testing using t-test statistical analysis at the significance level $(\alpha)=0.05$. Based on the calculation results obtained, $\mathrm{t}$-value $>\mathrm{t}$-table is $2.67>1.98$, decision was rejected Ho, which means there is an influence of the use of analogy in biology learning on critical thinking skills of high school students. The existence of this influence is seen in the differences in the scores of students' critical thinking skills in the experimental class and the control class.

The results of the pretest and posttest showed that the highest experimental class was 65 and 80 while in the control class were 58 and 74 . This showed that the results of the pretest and posttest in the experimental class were better than the control class because the scores in the experimental class were higher. High scores were in the experimental class because students were directed to analyze analogy used in learning so that the learning experience helped students' understanding. Learning directed at providing direct experience can help students gain a deeper understanding $[22,23]$.

The average score difference of students' critical thinking skills using analogy learning strategy was higher than using the STAD model. This was because in the learning process by using an analogy involving students' thinking in connecting analogy used with concepts learned by students, students are active in expressing their thought ideas. The analogy can train students' critical thinking skills and develop positive attitudes, such as critical, logical and analytical thinking as part of character education [21,24-27].

The analogy learning strategy and the STAD model applied to have in common, namely group discussion and presenting the results of group discussion. The analogy learning strategy influences students' critical thinking skills because students are directed to express their ideas and thus help them understand difficult concepts. This is because analogy can help students build concept bridges between something that is known and something new and 
help students build their own knowledge [21,24,27].

Learning strategy using analogy has the initial stages of introducing the concept of targets to students and reminding analog concepts that are known to students. In the initial stages, students are directed to know and recognize the concept of targets and analog concepts provided by the teacher. Next students analyze the target concepts and existing analog concepts by identifying relevant things, linking the same things and mismatches of the target concepts and analog concepts conveyed by the teacher and giving conclusions. These stages lead students to develop their thinking towards the concept of targets and analogy which are then analyzed for their suitability. The use of analogy in learning can be described as concept development and students will develop their thinking concepts $[12,21,28-30]$. In addition, these stages lead students in critical thinking, namely the stages of students'analyzing, identifying relevant things, connecting the same thing and the incompatible and giving conclusions. In this case, students involve testing, connecting, and evaluating all aspects of a situation or problem, including collecting, organizing, remembering, and analyzing information in their thought processes [11,31,32].

Learning by using analogy directs students to develop their thoughts and knowledge structures on information provided by the teacher, namely information in the form of topics, target concepts and analog concepts. Analogy learning can be said as constructive learning because students build their own knowledge structures based on their cognitive abilities. Students' knowledge cannot be transferred from the teacher's mind to the student's mind but the student is active in building his own knowledge structure $[33,34]$.

Complex and abstract concepts can be found in natural science, one of which is biology. The concept can be explained easily and simply by using an analogy. The use of analogy is more interesting because of its ability to explain complicated ideas in familiar terms. This is because analogy can help in understanding and communicating the complexity and difficulty of expressing an idea $[28,35]$.

Learning by using an analogy learning strategy is more interesting for students' learning interests because the analogy used in conveying concepts is easily known and uses students' everyday terms. For example, the use of the supermarket analogy to analogize biodiversity and environment is a topic that is conveyed at the time of learning. This is supported by the implementation of good learning. The use of analogy in learning can improve students' understanding of scientific concepts. In this case, the teacher needs to pay attention to the analogy to be used in conveying a concept to students so that students do not misunderstand what is conveyed by the teacher [36-40].

\section{Conclusions}

Based on the results of the study, it can be concluded that the use of analogy in biology learning affects the critical thinking skills of high school students on the topic of biodiversity and environment. The use of analogy in learning can be used as an alternative way for teachers to develop students' critical thinking skills in biology learning. The use of analogy can make it easier for students to receive complex biological concepts so that they are easily understood by students. Based on research, suggestions can be made that the use of analogy in the delivery of abstract concepts needs to be well developed in order to make it easier to understand the concepts to be conveyed. The need for further research on analogy in other fields is in order to add references and information due to the lack of reference material about an analogy for research, especially on the topic of biology. The use of analogy should be adjusted and discussed properly in accordance with the topics used to avoid mistakes.

\section{Acknowledgements}

The authors would like to thank all the students and teachers who have been participated in this research. The authors would also like to thank the expert who validating the research instrument.

\section{REFERENCES}

[1] Grant, M., \& Smith, M. (2018). Quantifying Assessment Of Undergraduate Critical Thinking. Journal of College Teaching \& Learning, 15(1), 27-38.

[2] Aizikovitsh-Udi, E., \& Amit, M. (2011). Developing the skills of critical and creative thinking by probability teaching. Procedia - Social and Behavioral Sciences, 15, 1087-1091. https://doi.org/10.1016/j.sbspro.2011.03.243

[3] Ennis, R. H. (2018). Critical Thinking Across the Curriculum: A Vision. Topoi, 37(1), 165-184. https://doi.org/10.1007/s11245-016-9401-4

[4] Orozco, J. A., \&Yangco, R. T. (2016). Problem-based learning: effects on critical and creative thinking skills in biology. Asian Journal of Biology Education, 9, 1-10.

[5] Demir, M., Bacanli, H., Tarhan, S., \&Dombayci, M. A. (2011). Quadruple thinking: Critical thinking. In Procedia Social and Behavioral Sciences. https://doi.org/10.1016/j.sbspro.2011.02.066

[6] Demiral, U. (2018). Examination of Critical Thinking Skills of Preservice Science Teachers: A Perspective of Social Constructivist Theory. Journal of Education and Learning, 7(4), 179. https://doi.org/10.5539/jel.v7n4p179

[7] Fauzi, A. (2019). Profile of Junior High School Students' Critical Thinking Skills in Answering Questions Related to 
Biological Concepts. Scientiae Educatia: Jurnal Pendidikan Sains, 8(1), 51-63.

[8] Fischer, E. (2018). Two analogy strategies: the cases of mind metaphors and introspection. Connection Science, 30(2), 211-243. https://doi.org/10.1080/09540091.2017.1350937

[9] Lee, Y. C. (2015). Self-generated Analogical Models of Respiratory Pathways. Journal of Biological Education, 49(4), https://doi.org/10.1080/00219266.2014.967275

[10] Miharja, F. J., Hindun, I., \&Fauzi, A. (2019). Critical thinking, metacognitive skills, and cognitive learning outcomes: a correlation study in genetic studies. Biosfer: Jurnal Pendidikan Biologi, 12(2), 135-143.

[11] Bustami, Y., Riyati, Y., \&Julung, H. (2019). Think talk write with pictured cards on human digestive system: impact of critical thinking skills. Biosfer: Jurnal Pendidikan Biologi, 12(1), 13-23.

[12] Rocha, S. D. (2015). Kinship, Analogy, and Experiment: A Collage. Journal of Curriculum and Pedagogy, 12(3), 241-251. https://doi.org/10.1080/15505170.2015.1095687

[13] Riddell, P. (2016). Metaphor, Simile, Analogy and the Brain. Changing English: Studies in Culture and Education, 23(4), 363-374. https://doi.org/10.1080/1358684X.2016.1228443

[14] Anderson, L. W., Krathwohl, D. R., Airiasian, W., Cruikshank, K. A., Mayer, R. E., \&Pintrich, P. R. (2001). A taxonomy for learning, teaching and assessing: A revision of Bloom's Taxonomy of educational outcomes: Complete edition. New York: Longman.

[15] Duran, M., \&Dökme, I. (2016). The effect of the inquiry-based learning approach on student's critical-thinking skills. Eurasia Journal of Mathematics, Science and Technology Education, 12(12), 2887-2908. https://doi.org/10.12973/eurasia.2016.02311a

[16] Vidergor, H. E., \&Krupnik-Gottlieb, M. (2015). High order thinking, problem based and project-based learning in blended learning environments. In Applied Practice for Educators of Gifted and Able Learners (pp. 217-232). https://doi.org/10.1007/978-94-6300-004-8_11

[17] Ali, S. S., Lifshitz, M., \& Raz, A. (2014). Empirical neuroenchantment: From reading minds to thinking critically. Frontiers in Human Neuroscience, 8, 1-4. https://doi.org/10.3389/fnhum.2014.00357

[18] Sung, H. Y., Hwang, G. J., \& Chen, S. F. (2019). Effects of embedding a problem-posing-based learning guiding strategy into interactive e-books on students' learning performance and higher order thinking tendency. Interactive Learning Environments, 27(3), 389-401. https://doi.org/10.1080/10494820.2018.1474235

[19] Ristanto, R. H,.Miarsyah, M., Muharomah, D.R., Astuti, T.A., Aini, S., \&Prihatin., A.I (2019). Light-Board: simple media to learn photosynthesis concepts. International Journal of Advanced Trends in Computer Science and Engineering, 9(1), 299-303. https://doi.org/10.30534/ijatcse/2020/45912020

[20] Arikunto, S., \&Jabar, C. S. A. (2004). Evaluasi program pendidikanpedomanteoritispraktisbagipraktisi Pendidikan. Jakarta: BumiAksara.
[21] Glynn, S., Taasoobshirazi, G., \& Fowler, S. (2007) Analogies: Explanatory tools in web-based science instruction. Educational Technology, 47(5), 45-50.

[22] Lestari, P., Ristanto, R., \&Miarsyah, M. (2019). Analysis of Conceptual Understanding of Botany and Metacognitive Skill in Pre-Service Biology Teacher in Jakarta, Indonesia. Journal for the Education of Gifted Young Scientists, 7(2), 199-214. https://doi.org/10.17478/jegys.515978

[23] Cronje, R., Rohlinger, S., Crall, A., \& Newman, G. (2011). Does Participation in Citizen Science Improve Scientific Literacy? A Study to Compare Assessment Methods. Applied Environmental Education and Communication, 10(3), $135-145$. https://doi.org/10.1080/1533015X.2011.603611

[24] Turney, P. D. (2011). Analogy perception applied to seven tests of word comprehension. Journal of Experimental and Theoretical Artificial Intelligence, 23(3), 343-362. https://doi.org/10.1080/0952813X.2010.502311

[25] Tse, C. Y. A., Wong, A., Whitehill, T., Ma, E., \& Masters, R. (2016). Examining the cognitive demands of analogy instructions compared to explicit instructions. International Journal of Speech-Language Pathology, 18(5), 465-472. https://doi.org/10.3109/17549507.2015.1112834

[26] Araya, R., Calfucura, P., Jiménez, A., Aguirre, C., Palavicino, M. A., Lacourly, N., ... Dartnell, P. (2010). The effect of analogies on learning to solve algebraic equations. Pedagogies: An International Journal, 5(3), 216-232. https://doi.org/10.1080/1554480X.2010.486160

[27] Lancor, R. A. (2014). Using Student-Generated Analogies to Investigate Conceptions of Energy: A multidisciplinary study. International Journal of Science Education, 36(1), 1-23. https://doi.org/10.1080/09500693.2012.714512

[28] Braasch, J. L., \& Goldman, S. R. (2010). The role of prior knowledge in learning from analogies in science texts. Discourse Processes, 47(6), 447-479.

[29] Aragón, M. del M., Oliva, J. M., \& Navarrete, A. (2014). Contributions of Learning Through Analogies to the Construction of Secondary Education Pupils' Verbal Discourse about Chemical Change. International Journal of Science Education, 36(12), 1960-1984. https://doi.org/10.1080/09500693.2014.887237

[30] Mammana, M. F., Micale, B., \&Pennisi, M. (2012). Analogy and dynamic geometry system used to introduce three-dimensional geometry. International Journal of Mathematical Education in Science and Technology, 43(6), 818-830. https://doi.org/10.1080/0020739X.2012.662286

[31] Santos, L. F. (2017). The Role of Critical Thinking in Science Education. Journal of Education and Practice, 8(20), 158-173.

[32] Yeung, S. yin S. (2015). Conception of teaching higher order thinking: perspectives of Chinese teachers in Hong Kong. Curriculum Journal, 26(4), 553-578 https://doi.org/10.1080/09585176.2015.1053818

[33] Churcher, K. M. A., Downs, E., \& Tewksbury, D. (2014). "Friending" Vygotsky: A Social Constructivist P edagogy of Knowledge Building Through Classroom Social Media Use. Journal of Effective Teaching, 14(1), 33-50. 
[34] Sesen, B. A., \&Tarhan, L. (2010). Promoting active learning in high school chemistry: Learning achievement and attitude. Procedia - Social and Behavioral Sciences, 2(2), 2625-2630. https://doi.org/10.1016/j.sbspro.2010.03.384

[35] Huang, J. S., \&Kapur, M. (2015). Can "less" create "more" in analogical reasoning? Learning: Research and Practice, $1(2)$,

https://doi.org/10.1080/23735082.2015.1071232

$133-151$.

[36] Coley, J. D., \& Tanner, K. (2015). Relations between intuitive biological thinking and biological misconceptions in biology majors and nonmajors. CBE Life Sciences Education, 14(1), 1-19. https://doi.org/10.1187/cbe.14-06-0094

[37] Keleş, E., \&Kefeli, P. (2010). Determination of student misconceptions in "photosynthesis and respiration" unit and correcting them with the help of cai material. Procedia Social and Behavioral Sciences, 2(2), 3111-3118. https://doi.org/10.1016/j.sbspro.2010.03.474

[38] Ningsih, L. R., Rusdi, R., \&Miarsyah, M. (2019). Exploring respiratory system to improve biological learning motivation: resysmart media application. Biosfer: Jurnal Pendidikan Biologi, 12(2), 211-222

[39] Handayani, G., Adisyahputra, A., \&Indrayanti, R. (2018). Correlation between integrated science process skills, and ability to read comprehension to scientific literacy in biology teachers students. Biosfer: Jurnal Pendidikan Biologi, 11(1), 22-32.

[40] Azrai, E. P., Evriyani, D., \&Prastya, A. R. (2016). Hubungantingkatkecemasansiswadalammenghadapitesden gantingkatmotivasibelajarbiologi pada siswakelas X MIA SMA Negeri 21 Jakarta. Biosfer: Jurnal Pendidikan Biologi, 9(1), 47-54. 